\section{Vegetation Changes as a Result of Soil Ripping on the Rio Puerco in New Mexico ${ }^{1}$}

\section{EARL F. ALDON AND GEORGE GARCIA}

Principal Hydrologist and Forestry Research Technician, Rocky Mountain Forest and Range Experiment Station, ${ }^{2}$ Albuquerque, New Mexico.

\section{Highlight}

Soil ripping in 1963 effectively reduced runoff on the San Luis watershed of the Rio Puerco, New Mexico, and caused a favorable shift in forage production from galleta to alkali sacaton. Ripping effects on runoff are short-lived, but forage production patterns may persist for 10 years.

Man's activity has a tremendous impact on the environment. Often a single goal in land treatment results in many subtle effects that are not readily discernible until some time later, sometimes with disastrous consequences. Soil ripping, for instance, a form of deep plowing to break up soil, effectively reduces surface runoff and erosion from semi-arid watersheds (Hickey and Dortignac, 1964). But what is the effect of this treatment on the vegetation growing on treated areas? The effect of soil ripping on the vegetation of one large area was investigated over a period of 15 years.

\section{Study Site and Methods}

The San Luis Watersheds on the Rio Puerco drainage are located 58 miles northwest of Albuquerque, New Mexico, in the transition zone between woodland and semi-desert grassland. The area is comprised of mesas or uplands, steep rocky breaks, and alluvial grasslands.

Watershed II, the test area, is 471 acres; Watershed I, left untreated for comparison, is 555 acres. On both of these watersheds, the headwaters originate on mesas that break off into steep, rocky slopes. These breaks give way to rolling foothills that merge with the alluvial bottoms. A layer of Mesa Verde sandstone overlies Mancos shale. The sandstone breaks and underlying shales form the parent soil material, the texture of which varies from sandy loams to silty clays. The area, which ranges in elevation from 6,000 to 7,000 feet, is typical of the larger semi-arid area in northwestern New Mexico.

The principal perennial grasses on the watersheds are alkali sacaton (Sporobolus airoides Torr.), galleta (Hilaria jamesii (Torr.) Benth.), and blue grama (Bouteloua gracilis (H.B.K.) Lag.). Shadscale saltbush (Atriplex confertifolia Torr. and Frem.), other saltbushes (Atriplex spp.) and big

${ }^{1}$ Research reported here was conducted in cooperation with the Bureau of Land Management, U.S. Department of the Interior, Albuquerque, New Mexico.

${ }^{2}$ U.S. Department of Agriculture, Forest Service, with central headquarters maintained at Fort Collins in cooperation with Colorado State University; authors are located at Albuquerque in cooperation with the University of New Mexico. sagebrush (Artemisia tridentata Nutt.) are the most common shrubs. Some pinyon pine (Pinus edulis Engelm.) and juniper (Juniperus spp.) trees and cholla cactus (Opuntia spp.) are scattered over the area.

Grazing on the area has been overwinter only (NovemberApril) since 1958. Numbers are adjusted to achieve 55\% utilization of alkali sacaton (Aldon and Garcia, 1967).

Average annual precipitation is close to 10 inches. Average growing-season precipitation (May 1-November 1) is around 6 inches. High-intensity convective thunderstorms characterize the summer storm period (July and August).

The S and S Soil Saver ${ }^{3}$ (Fig. 1) was used to rip the alluvial bottoms and other workable areas (slopes less than 5\%) in the spring of 1963 on Watershed II. The ripper was drawn on the contour by a large crawler-type tractor. The ripper has two chisels about 7 feet apart, with conical augers mounted behind each chisel. The augers revolve as they are pulled through the soil. This action cuts a 4-inch vertical rip approximately 28 inches deep, with a channel about a foot in diameter near the bottom of the rip. As the machine advances, two vertical triangular plates form small terraces about 4 inches high on each side of the rips.

Herbage production of the principal grasses was determined by a weight-estimate (Pechanec and Pickford, 1937) and double-sampling technique (Wilm et al., 1944). Measurements have been taken on 75 permanent $9.6-\mathrm{ft}^{2}$ plots randomly located on each watershed each fall after growth of forage has stopped since 1955.

The loop transect method (Parker, 1951) was used as an index to changes in ground cover due to treatment. Twentyfive clusters of three $100-\mathrm{ft}$ transects were randomly distributed over the watersheds. "Hits" of perennial vegetation, bare soil, litter, and rock within a $3 / 4$-inch loop placed at I-foot intervals along the 100 -foot transects were recorded. Perennial vegetation must have the root crown, or a portion thereof, within the loop to constitute a "hit."

Summer runoff was collected and measured behind earthen dams.

\section{Results}

The soil ripping treatment effectively stopped runoff on the treated watershed. The treatment effectiveness has been diminishing gradually, as expected, since the third year (Aldon, 1966).

Ground cover has been improving on the area since grazing management was started (Aldon and Garcia, 1967). Alkali sacaton and galleta occur about the same number of times on the watershed, with galleta occasionally showing one or two more hits. In 1963, ripping caused a temporary $28 \%$ decline in perennial grass cover. This decline was about equal for each of the three principal species.

Total forage production has also been improving on the areas since grazing management was started (Aldon and Garcia, 1967) in spite of variable precipitation (Table 1). When the percent contribution of each species to total forage production is graphed, a marked response to the ripping treatment is apparent (Fig. 2). From 1955 to 1962,

${ }^{3}$ Trade names are used for the benefit of the reader, and do not imply endorsement or preferential treatment by the U.S. Department of Agriculture. 


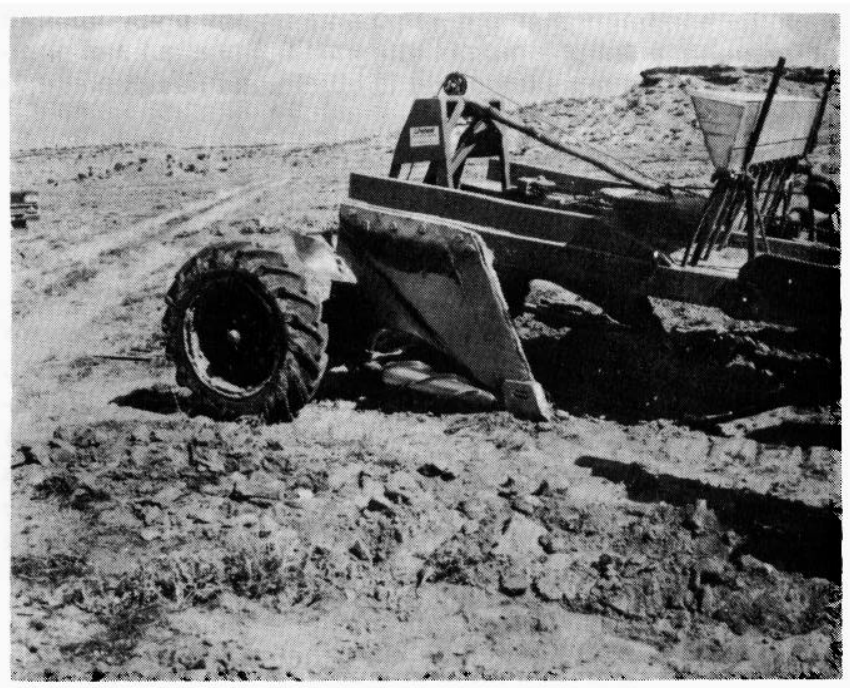

Fig. 1. The soil ripper, pulled behind a crawler tractor, effectively breaks up soil to a depth of about 28 inches.

galleta provided over half of the total forage production. Untreated Watershed I shows about this same relationship. Since Watershed II was treated, alkali sacaton has produced over half of the forage (Fig. 2). The trend since treatment, however, is to revert back gradually to the original relationship.

Blue grama has contributed about 10 percent of the total forage throughout the 15 years of study.

\section{Discussion}

Individual alkali sacaton plants are now producing more forage as a result of treatment. The
Table 1. Growing-season precipitation (inches) for Watershed II (ripped in 1963) and production of principal grasses (lb./acre, air dry) on Watersheds I and II.

\begin{tabular}{|c|c|c|c|c|c|c|c|}
\hline \multirow[b]{2}{*}{ Year } & \multirow[b]{2}{*}{ Precipitation } & \multicolumn{2}{|c|}{$\begin{array}{c}\text { Alkali } \\
\text { sacaton }\end{array}$} & \multicolumn{2}{|c|}{ Galleta } & \multicolumn{2}{|c|}{$\begin{array}{l}\text { Blue } \\
\text { grama }\end{array}$} \\
\hline & & I & II & I & II & I & II \\
\hline 1955 & 6.35 & 27 & 42 & 74 & 105 & 39 & 17 \\
\hline 1956 & 2.20 & 15 & 20 & 48 & 45 & 14 & 5 \\
\hline 1957 & 8.16 & 27 & 36 & 84 & 53 & 16 & 8 \\
\hline 1958 & 6.44 & 49 & 88 & 126 & 110 & 61 & 33 \\
\hline 1959 & 6.84 & 68 & 55 & 134 & 118 & 46 & 15 \\
\hline 1960 & 5.42 & 45 & 52 & 151 & 86 & 33 & 13 \\
\hline 1961 & 9.59 & 87 & 72 & 144 & 137 & 59 & 20 \\
\hline 1962 & 2.32 & 112 & 88 & 199 & 193 & 69 & 23 \\
\hline 1963 & 3.94 & 111 & 123 & 176 & 118 & 57 & 24 \\
\hline 1964 & 6.57 & 86 & 289 & 207 & 159 & 44 & 28 \\
\hline 1965 & 9.02 & 1 & 255 & 1 & 115 & 1 & 25 \\
\hline 1966 & 6.05 & & 295 & & 156 & & 44 \\
\hline 1967 & 9.08 & & 276 & & 164 & & 41 \\
\hline 1968 & 5.60 & & 293 & & 180 & & 52 \\
\hline 1969 & 11.57 & & 338 & & 230 & & 83 \\
\hline 1970 & 5.92 & & 299 & & 222 & & 67 \\
\hline
\end{tabular}

${ }^{1}$ Measurements discontinued due to loss of grazing control.

treatment's effectiveness for runoff and erosion control is short-lived, but its effect on plants-a favorable shift in forage importance from galleta to alkali sacaton-has continued for seven years. It may take another 3 to 5 years until the original relationship is re-established.
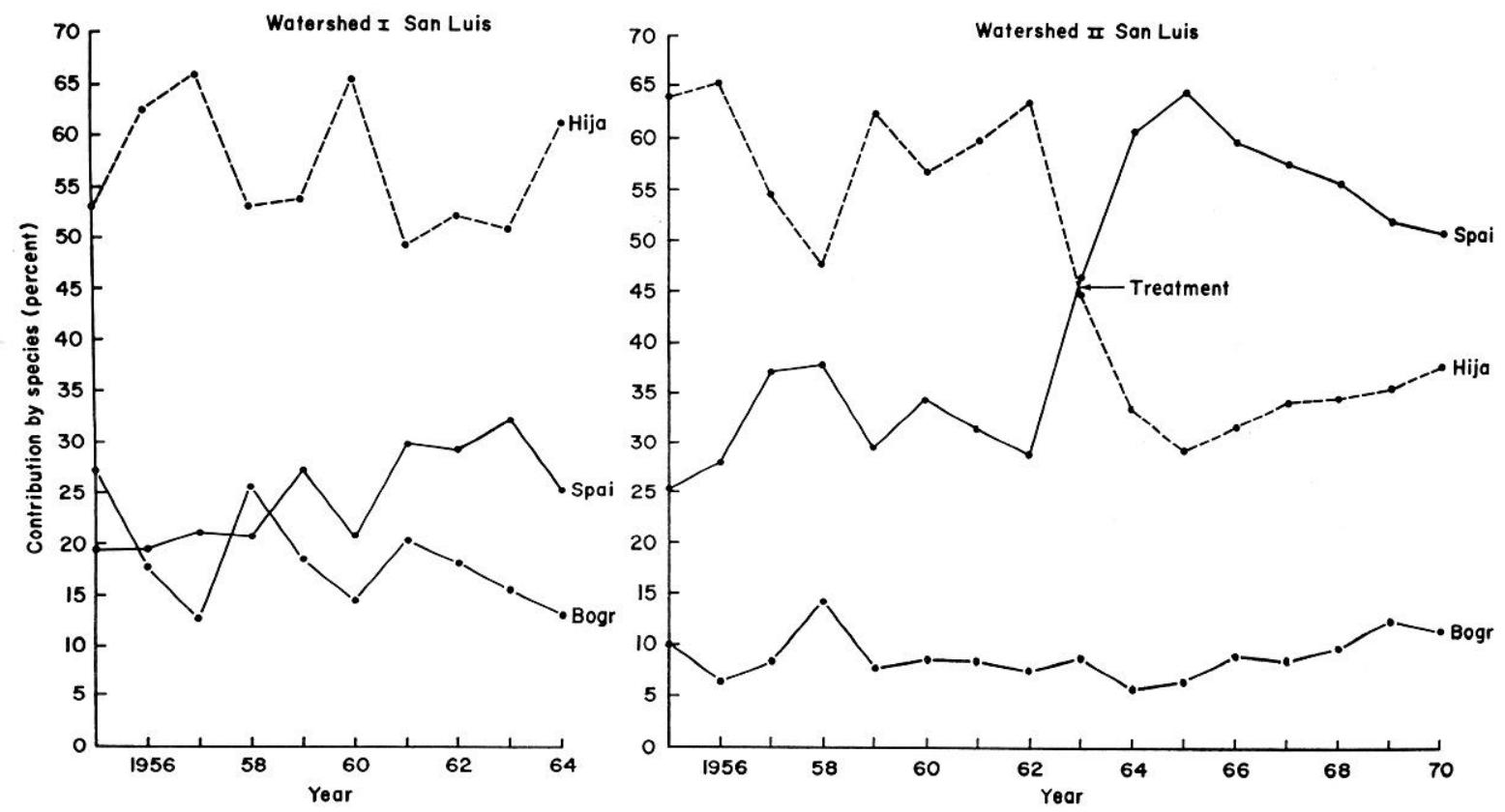

FIG. 2. Percent contribution, by species, to total annual forage production on Watershed I (left) and Watershed II (right). Bogr $=$ blue grama, $\mathrm{Hija}=$ galleta and Spai $=$ alkali sacaton . 


\section{Literature Cited}

ALdon, EARL F. 1966. Deferred grazing and soil ripping improves forage on New Mexico's Rio Puerco drainage. N. Mex. Stockman 31(11):44-46.

Aldon, Earl F., ANd G. Garcia. 1967. Summer deferred grazing can improve deteriorated semi-desert ranges. U.S. Forest Serv. Res. Note RM-95, 3 p., Rocky Mt. Forest and Range Exp. Sta., Fort Collins, Colo.

Hickey, Wayne C., JR., and E. J. Dortignac. 1964. An evaluation of soil ripping and soil pitting on runoff and erosion in the semi-arid Southwest. Internatl. Union
Geodesy and Geophys., Internatl. Assoc. Sci. Hydrol., Land Erosion, Precipitation, Hydrometry, Soil Moisture Comm. Pub. 65:22-23, illus.

PARKER, K. W. 1951. A method for measuring trend in range condition on national forest ranges. U.S. Forest Serv., Washington, D.C. 26 p., illus. (Processed).

Pechanec, J. F., and G. D. Pickford. 1937. A weightestimate method for determination of range or pasture production. Agron. J. 29:894-904.

Wilm, H. G., D. F. Costello, and G. E. Klipple. 1944. Estimating forage yield by the double-sampling method. Agron. J. 36:194-203. 